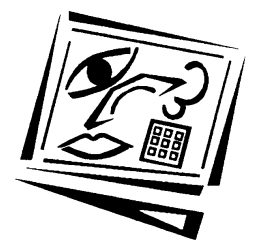

\title{
Using learning styles data to inform e-learning design: A study comparing undergraduates, postgraduates and e-educators
}

\author{
Julie Willems \\ University of New England
}

\begin{abstract}
What are the differences in learning styles between students and educators who teach and/or design their e-learning environments? Are there variations in the learning styles of students at different levels of study? How may we use this learning styles data to inform the design in e-learning environments? This paper details mixedmethods research with three cohorts teaching and learning in e-learning environments in higher education: novice undergraduate e-learners, graduate e-learners, and educators teaching in, or designing for, e-learning environments (Willems, 2010). Quantitative findings from the Index of Learning Styles (ILS) (Felder \& Silverman, 1988; Felder \& Soloman, 1991, 1994) reflect an alignment of the results between both the graduate e-learner and e-educator cohorts across all four domains of the ILS, suggesting homogeneity of results between these two cohorts. By contrast, there was a statistically significant difference between the results of the graduate and educator cohorts with those of the undergraduate e-learners on two domains: sensing-intuitive $(p=0.015)$ and the global-sequential $(p=0.007)$, suggesting divergent learning style preferences. Qualitative data was also gathered to gain insights on participants' responses to their learning style results.
\end{abstract}

\section{Introduction}

Over the years, the term e-learning has been employed in a multitude of ways. Coined in the late 1990s (Morri, 1997; Cross, 1998; Clark, 2007), the term e-learning was pervasively defined in relation to technology (Bowles, 2004) - the ' $\mathrm{e}$ ' in e-learning relating to the 'how' of the electronic storage of digitised learning materials (Clark \& Mayer, 2011). At the time of its coinage, the technology in focus related mainly to ways that computers could deliver and manage instruction (Driscoll, 2002). More recently, however, the definition of e-learning has evolved to accommodate the addition of wireless and mobile technologies, and immersive virtual worlds. As a consequence, technology-specific terminologies are now considered sub-sets of e-learning (Siemens, 2004; Fournier et al., 2006).

However, Wheeler (2007) writes that defining e-learning purely from a technological perspective does education a great disfavour as it considers only the technology and not the 'learning' aspect of the dynamic - encompassing education, instruction, teaching, training and tutoring (Anohona, 2005) - which, some argue, should be the major focus (Roffe, 2002; Oblinger \& Hawkins, 2005; Conner \& Conner, 2006). The 'learning' in e-learning relates to 'what' and 'why'; specifically, "the content and ways to help people learn it [in order to] achieve educational goals or to help organizations 
build skills related to improved job performance" (Clark \& Mayer, 2011, pp. 11-12). To this, I would add the 'where' of e-learning - the context of this instruction or learning and modes of participation (Willems, 2005). This shift is captured by such e-learning definitions as "the use of digital technologies to support the processes of teaching and learning" (Gibbs \& Gosper, 2006, p. 46) and "instruction that is delivered on a digital device such as a computer or mobile device that is intended to support learning" (Clark \& Mayer, 2011, p. 8). Further, with the advent of Web 2.0 - 'e-learning 2.0' (Downes, 2005) - key features such as content (co-)creation, sharing and collaboration (Karrer, 2007) have further expanded how e-learning is conceived. Consequently, contemporary definitions have broadened to encompass all the 'how', 'what', 'where' and 'where' aspects of e-learning.

Instructional design (ID) includes the planning and development of e-learning (Brown \& Voltz, 2005). Wagner (2011) argues that ID should not be viewed as a process, but rather as the development of a product which, in order to be successful, must include an analysis of the learner, the context and the situation; the design of the learning intervention; its development and production; and implementation and evaluation. The analysis of the learner and considering their individual differences in ID is a learner-centred, learner-responsive approach (McLoughlin, 1999) and learning style preferences is one aspect of these considerations (Sims \& Sims, 2006; Graf \& Kinshuk, 2007; Brown et al., 2009). Further, it is a research focus that is gaining attention in the field of e-learning, in part catalysed by growing frustration by many with the 'onesize-fits-all' approaches to ID (Clark \& Mayer, 2011). For as Vandiver and Walsh (2010) note, not all students learn through the same experiences or via the same modes of teaching: what works for one does not necessarily work for another, and thus considering alternative approaches to teaching and learning within ID is essential. To cater for learning style diversity, instruments such as the Index of Learning Styles (ILS) (Felder \& Silverman, 1988; Felder \& Soloman, 1991, 1994) provide a useful 'litmus test' (Willems, 2010) to ensure that ID is balanced (Felder \& Spurlin, 2005; Felder \& Brent, 2005).

\section{Learning style preferences}

Felder and Brent (2005) argue that one aspect of student diversity is learning style preferences. While the main body of academic literature surrounding learning styles extends from the mid twentieth century to the current day, learning styles can be traced back to the book of Daniel (circa 6th century BC) where an aptitude for different types of learning is recognised by the author (chapter 1, verse 4, NIV Study Bible, 1985). Centuries later, it was a research focus in 1898 by Montessori and her colleagues Hewitt and Dewey who examined the influence of learning styles in their study of pedagogical anthropology (Ford, 1997, cited in Greenman, 2005, p. 266). Learning styles make common sense (Coffield et al., 2004; Clark \& Mayer, 2011) - or are considered intuitive (Ryan, 2009) - for approximately $90 \%$ of the population (Willingham, 2008).

Learning styles research has now become a broad field encompassing a wide array of assessment instruments (Peschler et al., 2008) which are built on various philosophical bases (Butler, 1986). In all, there are over 71 models which can be apportioned into a spectrum of five learning style 'families' based on certain similarities and differences (Coffield et al., 2004). The field is divided over whether learning styles are inflexible or can change over time, leading to a group of learning style instruments/theories at one end of the spectrum which consider learning styles to be fixed and hard to modify 
behaviours, through to learning styles as adaptations to the students' educational experiences at the other end (Coffield et al., 2004). As such, definitions of learning styles are divergent.

The definition of learning styles adopted in this article comes from the fourth 'family': a "learning style is not a fixed trait, but a differential preference for learning" (Coffield et al., 2004, p. 61). This group holds that learning style preferences are flexibly stable and that learning is "the result of the transaction between social knowledge and personal knowledge" (Kolb, 1984, p. 36, as cited in Coffield et al., 2004, p. 62). Felder (2007, n.p.) summarises this position:

\begin{abstract}
learning styles are not immutable aspects of personality that people are born with and die with. I see them as preferences that may be mild, moderate, or strong, and "flexibly stable" is a good term to describe them. They shift over time and are influenced by life experiences. In some cases - especially if their initial preferences are mild - people switch from one category to its opposite, perhaps starting out as mild sensors and turning into mild intuitors or vice versa, but I think that a moderate or strong preference switching to its counterpart is probably quite rare.
\end{abstract}

Felder and Spurlin (2005) argue that environmental factors, plus an individual's previous learning experiences, assist in the formation of learning styles. This position resonates for this researcher, for if we consider the goal of education is to produce new personal knowledge and skills (whichever epistemological perspective undergirds our approach to education) then it follows that in the process of learning those skills, adaptations in learning style preferences can occur over time. Tucker, $(2007$, p. 247) has termed this flexibility as "drift".

However, learning styles can be a contentious field of study. The controversy stems in part from divergent practices within the field (Bolea, 2006), such as the uses to which some learning style results are put (Felder, 2006); the "thriving commercial industry" that some have generated (Coffield et al., 2004, p. 119); the validity of some learning style data (Suskie, 2002); and the arguments for and against 'matching' learning styles with teaching styles in the (e-) learning design (Peschler et al., 2008). On this latter point, some proponents argue that learning environments and instructional methods should be 'matched' (Suskie, 2002), 'meshed' (Pashler et al., 2008), or 'modified' (Kratzig \& Arbuthnott, 2006) to an individual's learning style for optimal learning. This leads critics such as Willingham (2008) to debunk the notion of learning styles, stating that "we don't need to adjust our teaching to individual learning styles". However, others argue that a mismatch is necessary for learning to take place (Grasha, 1984). A third group argue that the way in which we teach matters and that learning environments need to be balanced and scaffolded to enhance learning (Felder \& Brent, 2005).

If learning styles is such a contentious area of study why undertake such research? Felder and Spurlin (2005) argue that there are two main applications and these relate to key stakeholder groups in e-learning provision. The first, they argue, is that learning style preferences help educators understand learner diversity. They provide a reminder to educators to make learning environments balanced (Felder \& Brent, 2005) and varied (Rojas, 2009), with implications for ID of e-learning environments (Hou et al., 2010). Further, when learning fails, learning styles can provide a starting point to consider the role that educators and ID might play in remediation (Coffield et al., 2004; Willems \& Reed, 2007). Thus considering learning styles in ID can be transformative. The second benefit is that it can assist learners in developing a sense of their own 
individual learning preferences (Suskie, 2002) and provide them with insights into their own individual strengths and weaknesses (Bowles, 2004; Felder \& Spurlin, 2005) so that they may better manage their learning. As such, it may also be personally empowering. A third additional application concerns another group of stakeholders. For administrators and institutions offering e-learning opportunities, a consideration of learning styles in ID promotes student-centred learning which is a focal point in current debates on the future of Australian higher education and related funding (Gillard, 2009). Students may be drawn to educational institutions that both recognise and provide for diverse learning styles (Dede, 2005). Those which cater in some ways towards individuality in the learning environment may have a marketing edge in a globally competitive marketplace.

In general, learning styles relate to individual learning preferences on processing, perceiving, receiving and understanding information. However, previous research has also identified potential learning style homogeneity within particular groups of learners, for example those from different cultural backgrounds (Kleinfeld \& Nelson, 1991; Allinson \& Hayes, 2000; Mariani, 2004); gender (Belenky et al., 1986; Philbin et al., 1995; Leiba \& Nachmias, 2006); disciplines/faculties (Lopes, 2002); undergraduates (Morrison et al., 2003; Leiba \& Nachmias, 2006; Brown et al., 2009; Bousbia et al., 2010); or educators (Rosati, 1999; Lopes, 2002; Zywno, 2003).

At the time that this study was commenced - 2004 - little research had been conducted on learning styles specifically relating to online, e-learning or virtual learning environments (Bousbia et al., 2010). Until relatively recently, the majority of learning styles research has examined face to face learning contexts, although studies have since begun to fill this gap (see for example, Brown et al., 2009). Two areas for which Felder and Brent (2005) suggest that further learning style research could be conducted are in the learning style differences between students and the educators who teach them, and variations in the learning styles of students at different levels of study in academia. This noted gap was the focus of this research project.

\section{The Index of Learning Styles (ILS)}

One learning styles instrument from the fourth group on the learning styles spectrum (Coffield et al., 2004) is the Index of Learning Styles (ILS) (Felder \& Silverman, 1988; Felder \& Soloman, 1991, 1994). There are four separate domains on the ILS, with two aspects at each end of the continua (Felder, 1993). The description to follow of each domain is based on those provided by Felder and Brent (2005) and Felder and Spurlin (2005). The first domain considers the manner in which individuals prefer to process information - ranging from active (physical engagement or discussion) through to reflective (introspective thought processes) learning style preferences. The second domain (sensing-intuitive) examines the way that individuals prefer to perceive information. Sensing learners are concrete thinkers who are practically oriented, preferring learning through sights, sounds and physical sensations) whereas intuitive learners are abstract thinkers who are theoretically oriented and prefer to learn through memories, thoughts, and insights. The third domain concerns itself with how individuals prefer to receive information - ranging from visual (pictures, diagrams, graphs, or demonstrations) through to verbal (written and spoken words) learning style preferences. The fourth domain spans the manner in which an individual progresses towards understanding - ranging from sequential (logical or incremental steps; linear thought) through to global (learning in 'big picture' leaps; systems-oriented thought) learning style preferences. 
The ILS measures the strength of preference on each of these four domains. A score of 1 or 3 on either side of a domain indicates a weak preference for that particular category, suggesting that the individual is reasonably balanced on both dimensions of that scale (Felder \& Soloman, 1991, 1994); a score of 5 or 7 indicates a moderate preference; and a score of 9 or 11 indicates a strong preference (Figure 1).

INDE X OF LE ARNING STYLES (ILS) RE PORT FORM

Adapted from Felder and Soloman (1991, 1994)

http//www.ncsu edu felder-public.ILSdir.ILS. pdf.

PROCESSING INFORMATION

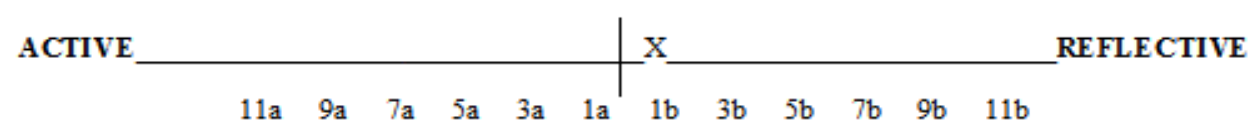

PERCEIVING INFORMATION

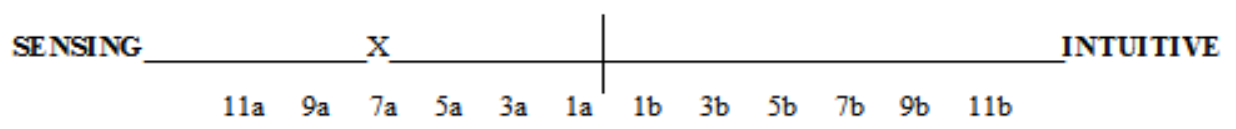

RECEIVING INFORMATION

VISUAL $\mathrm{X}$ VERBAL

$\begin{array}{llllllllllll}11 \mathrm{a} & 9 \mathrm{a} & 7 \mathrm{a} & 5 \mathrm{a} & 3 \mathrm{a} & 1 \mathrm{a} & 1 \mathrm{~b} & 3 \mathrm{~b} & 5 \mathrm{~b} & 7 \mathrm{~b} & 9 \mathrm{~b} & 11 \mathrm{~b}\end{array}$

UNDERSTA NDING INFORMATION

$\begin{array}{lllllllllllllll}\text { SEQUENTIAL } & \mathbf{X} & & & & & & & \text { GLOBAL }\end{array}$

Figure 1: ILS report form

\section{Research methods}

The research explored what are the differences in learning styles between students at different levels of study; the differences between learners and educators in e-learning environments; and considered how this data may be used to inform ID. Solutions to overcome four challenges were considered in the research design. The first is that rigour and care are necessary in the selection of the specific learning styles instrument to use (Coffield et al., 2004), ensuring the validity and reliability of the model used (Bolea, 2006). For this purpose, the ILS was chosen as it is considered to be valid and reliable (Felder \& Spurlin, 2005; Hou et al., 2010). Second, learning style instruments are quantitative methods of data collection. They tend to be fixed response (closed 
answer) instruments which do not allow individual (Suskie, 2002) or qualitative input. As such, it was considered beneficial to add a means to collect qualitative responses to add depth and insight to the research. A third critique is that learning style instruments may be completed without reference to a specific learning context - or learning space - in mind, resulting in the responses not corresponding to the actual situation (Paredes \& Rodríguez, 2004). This was addressed by focussing the participants on their experiences within their specific e-learning environment. A fourth consideration that also guided the research design was that the data collection instruments needed to be simple to use within electronic settings, and could be completed either online or printed, completed by hand and posted by traditional means, thus catering for respondent preferences.

Following ethics approval, purposive sampling (Cohen \& Manion, 1994) of cohorts known to be teaching and learning in e-learning environments - and for whom permission to access had been granted - took place in 2005. This initial recruitment strategy was centred around novice e-learners enrolled in a first-year undergraduate course in the School of Humanities, Communications and Social Sciences, Faculty of Arts, Monash University; graduate e-learners enrolled in the School of Communications at Victoria University Wellington; and e-educators who were either teaching in and/or designing for e-learning environments in both schools at Monash University and Victoria University. Participants who expressed interest in taking part in the study were assigned a code comprising three category designations - ' $U$ ' (undergraduate e-learners), ' $G$ ' (graduate e-learners), and ' $E$ ' (educators) - with each letter identifier being followed by a numeral, for example, 'E31' (Figure 1). These identifiers were marked on all related data and email correspondence. Discrepancies between the allocated identifiers and the reported cohort numbers (for example 'E35' in the educator cohort) are due to non-completion of both research instruments by interested participants.

Participants were requested to complete the two data collection instruments simultaneously. This enabled mixed method data collection of quantitative data, qualitative open responses, and contextualised participant responses to the specific elearning environment. As noted, the first of the two data collection instruments was Felder and Soloman's Index of Learning Styles (ILS) (1991, 1994), a quantitative data collection instrument. On completion of the ILS, the responses were scored and the results entered onto a codified results sheet (Figure 1). Participants were then sent an electronic copy of their ILS results. The ILS report form also contained a hyperlink to Learning Styles and Strategies (Felder \& Soloman, 1993) which details the strengths of each learning style preference in addition to ways of maximising learning according to the different styles along with options to overcome challenges if educational material is delivered in a format counter to the participant's preferred way of learning. Participants were then invited to provide comment on whether they felt that the ILS result was compatible with how they perceived themselves.

The second instrument to be completed by each participant was a survey questionnaire. Two similar but separate survey questionnaires were created: one for the undergraduate and graduate e-learner cohorts, and the other for the educators. Part A of the Survey Questionnaire $(S Q)$ was constructed to gather demographic data on the respondent. While participants' learning style preferences across each of these demographic points was not examined, the data can be reanalysed at a later date. Part $B$ of the $S Q$ gathered qualitative responses on participant's experiences in their e- 
learning environment and in relation to their learning style preferences. The openended questions were based on the four domains of learning style preferences, using similar wording to the ILS so as to enable comparison of the participants' responses with their ILS profiles. The questionnaire was initially piloted on a small group of individuals to check for any discrepancies before being released to the larger research cohorts. Qualitative data was also collected through subsequent interviews, and/or email correspondence. The thematic analysis of this qualitative material and its comparative triangulation to the quantitative data is beyond the scope of this publication and will be reported in a separate paper.

Sufficient participant numbers were slow to eventuate in all three cohorts from these institutions, and following ethics amendments, an invitation for participation was made to both conference delegates (educators working in e-learning environments) and their student cohorts at several Australasian e-learning conferences in late 2005 and 2006. As a consequence of this extended invitation, the increased response rate resulted in healthier cohort numbers in both the e-educator and undergraduate elearner cohorts; however the graduate e-learner cohort response rate remained low. In all, 48 undergraduate e-learners, 10 graduate e-learners and 31 e-educators took part in the study. Of this number, 2 undergraduate e-learners, 1 graduate e-learner and 2 eeducators did not complete the ILS as one of the twin data-collection instruments despite follow-up and, as such, their data is not included in this paper. Therefore, the responses of 46 novice undergraduate e-learners, 9 graduate e-learners, and 29 educators are reported here.

\section{Quantitative results}

The ILS results in this study are reported in the typical format of the combining the learning style preferences that fall on each side of the four domains and reporting them in two groupings - for example, 'visual' and 'verbal' learning styles - in order to enable cross-study comparison. Note, however, that a more recent manner of reporting ILS data splits the results into three groupings across each of the four domains - for example, 'moderate-strong visual', 'moderate-strong verbal', and a mid-grouping of 'weak/mild visual or verbal' (see, for example, Brown et al., 2009).

The quantitative data were subjected to non-parametric tests, which was a necessity due to the small number of respondents in the graduate cohort. The Kruskall Wallis Test (chi-squared analysis) was run for comparison of results across the four individual domains of the ILS, while the Mann-Whitney U Test was run for comparison between the cohorts. There was a mild preference for active learning and a moderate preference for visual learning across all three cohorts. The undergraduate elearners scored a mild preference for sensing and sequential learning. In contrast, both the graduate and e-educator cohorts scored a moderate preference for intuitive learning and a mild preference for global learning (Table 1 and Figure 2).

The disparity between the results of undergraduates and the graduate and educator cohorts was deemed statistically significant on two of the four domains of the ILS: sensing-intuitive $(p=0.015)$ and sequential-global $(p=0.07)$ (Table 1$)$. These ILS findings also support other research findings. Felder and Spurlin (2005) and Graf (2007) have both noted two points of correlation on the ILS between the sensingintuitive and sequential-global domains. 
Table 1: Three-cohort comparison of ILS results across four domains

\begin{tabular}{|c|c|c|c|c|c|c|c|c|}
\hline ILS Domains & \multicolumn{2}{|c|}{$\begin{array}{c}\text { Domain } 1 \\
\text { Processing } \\
\text { information }\end{array}$} & \multicolumn{2}{|c|}{$\begin{array}{c}\text { Domain } 2 \\
\text { Perceiving } \\
\text { information }\end{array}$} & \multicolumn{2}{|c|}{$\begin{array}{c}\text { Domain } 3 \\
\text { Receiving } \\
\text { information }\end{array}$} & \multicolumn{2}{|c|}{$\begin{array}{c}\text { Domain } 4 \\
\text { Understanding } \\
\text { information }\end{array}$} \\
\hline Cohorts & Active & $\begin{array}{l}\text { Reflec- } \\
\text { tive }\end{array}$ & Sensing & $\begin{array}{l}\text { Intui- } \\
\text { tive }\end{array}$ & Visual & Verbal & $\begin{array}{l}\text { Sequen- } \\
\text { tial }\end{array}$ & Global \\
\hline $\begin{array}{l}\text { Undergraduate e-learner } \\
(\mathrm{n}=46)\end{array}$ & $54 \%$ & $46 \%$ & $61 \%$ & $39 \%$ & $87 \%$ & $13 \%$ & $52 \%$ & $48 \%$ \\
\hline Graduate e-learner $(n=9)$ & $56 \%$ & $44 \%$ & $22 \%$ & $78 \%$ & $78 \%$ & $22 \%$ & $22 \%$ & $78 \%$ \\
\hline E-educator $(n=29)$ & $59 \%$ & $41 \%$ & $38 \%$ & $62 \%$ & $72 \%$ & $28 \%$ & $24 \%$ & $76 \%$ \\
\hline$p$ value & \multicolumn{2}{|c|}{$p=.800$} & \multicolumn{2}{|c|}{$p=.015$} & \multicolumn{2}{|c|}{$p=.588$} & \multicolumn{2}{|c|}{$p=.007$} \\
\hline
\end{tabular}

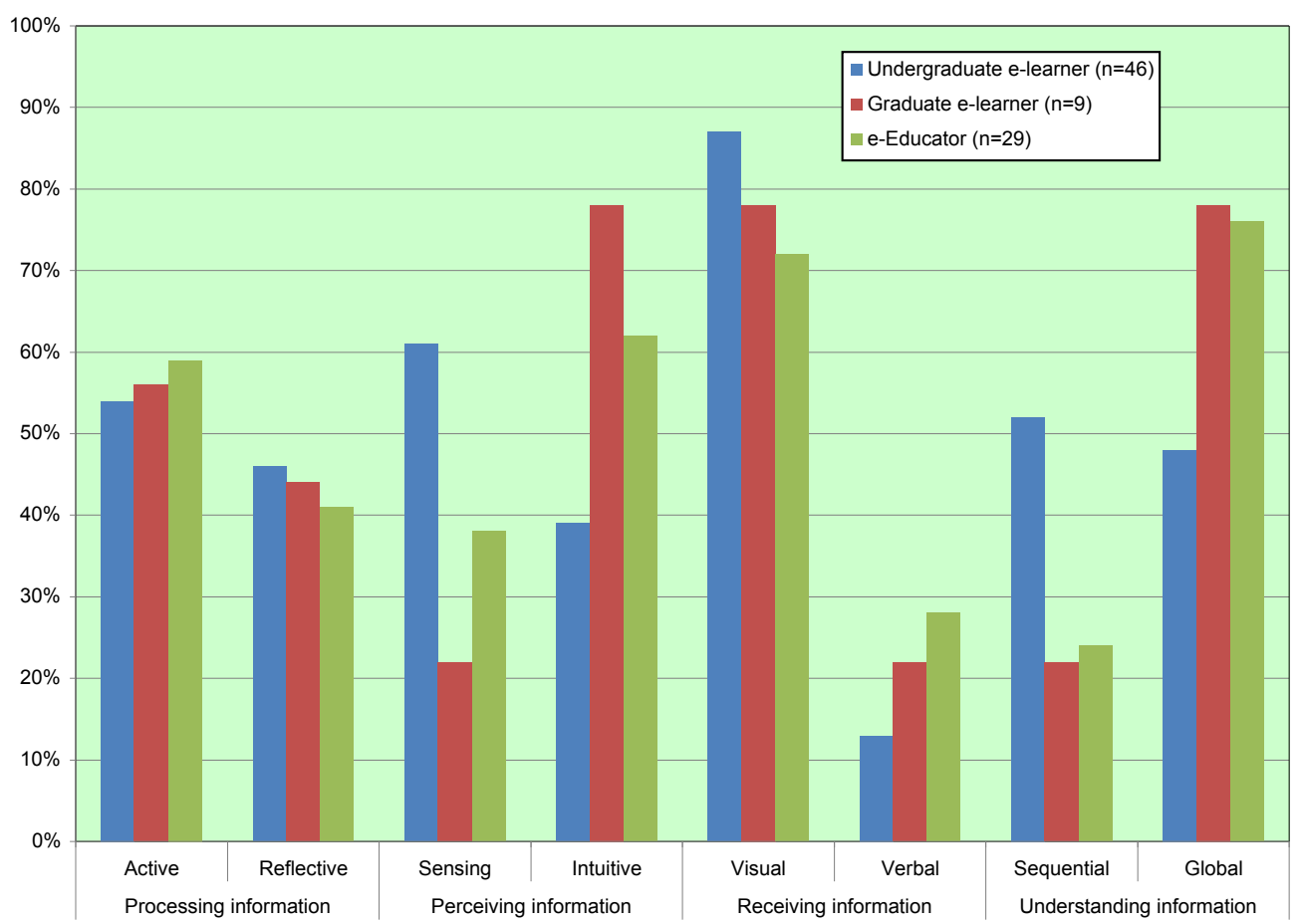

Figure 2: Three-cohort comparison of ILS results across four domains

The learning style preferences for the novice undergraduate e-learner $(\mathrm{U})$ cohort in this study were for active learning (54\%), sensing learning $(61 \%)$, visual learning $(87 \%)$, and sequential learning (52\%). Due to small sample sizes in part brought about by limited access to research participants due to privacy barriers, the generalisation of these research findings is problematic. However, the results of the undergraduate cohort in this study are comparable to the findings of larger-scale ILS studies whose findings have been deemed generalisable to the broader population. For example, Felder and Spurlin (2005) calculated the mean of ten international studies of undergraduate engineering student populations in face to face contexts $(n=1300)$ and found similar results for undergraduate learning style preferences: active learning $(61 \%)$, sensing learning $(63 \%)$, visual learning $(82 \%)$ and sequential learning $(59 \%)$, as displayed in Table 2. 
Table 2: Comparison of undergraduate e-learner cohort with international mean

\begin{tabular}{|l|c|c|c|c|}
\hline \multicolumn{1}{|c|}{ Undergraduate comparison } & Active & Sensing & Visual & Sequential \\
\hline $\begin{array}{l}\text { Current study: undergraduate e-learner } \\
\text { cohort ( } \mathrm{n}=46 \text { ) }\end{array}$ & $54 \%$ & $61 \%$ & $87 \%$ & $52 \%$ \\
\hline $\begin{array}{l}\text { Felder and Spurlin (2005) international mean } \\
\text { undergraduate students (n=1300) }\end{array}$ & $61 \%$ & $63 \%$ & $82 \%$ & $59 \%$ \\
\hline
\end{tabular}

The ILS results of the graduate e-learner (G) and e-educator (E) cohorts in this study were aligned across all four domains (Table 3 ), with a preference for active learning $(\mathrm{G}=56 \% ; \mathrm{E}=59 \%)$, intuitive learning $(\mathrm{G}=78 \%$; $\mathrm{E}=62 \%)$, visual learning $(\mathrm{G}=78 \%$; $\mathrm{E}=72 \%)$, and global learning $(\mathrm{G}=78 \% ; \mathrm{E}=76 \%)$. Both the graduate e-learner and e-educator cohorts diverged with the learning style preferences of the undergraduate e-learner cohort on the sensing-intuitive and sequential-global dimensions. As noted, this discrepancy is deemed statistically significant.

Table 3: Comparison of e-educator and graduate e-learner cohort with international studies

\begin{tabular}{|l|c|c|c|c|c|c|c|c|}
\hline \multicolumn{1}{|c|}{ Sampled population } & Active & $\begin{array}{c}\text { Refl- } \\
\text { ective }\end{array}$ & $\begin{array}{c}\text { Sens- } \\
\text { ing }\end{array}$ & $\begin{array}{c}\text { Intui- } \\
\text { tive }\end{array}$ & Visual & Verbal & $\begin{array}{c}\text { Seque- } \\
\text { ntial }\end{array}$ & Global \\
\hline $\begin{array}{l}\text { Current study: graduate e- } \\
\text { learner cohort (n=9) }\end{array}$ & $56 \%$ & $44 \%$ & $22 \%$ & $78 \%$ & $78 \%$ & $22 \%$ & $22 \%$ & $78 \%$ \\
\hline $\begin{array}{l}\text { Current study: e-educator } \\
\text { cohort (n=29) }\end{array}$ & $59 \%$ & $41 \%$ & $38 \%$ & $62 \%$ & $72 \%$ & $28 \%$ & $24 \%$ & $76 \%$ \\
\hline $\begin{array}{l}\text { Zywno (2003) Ryerson } \\
\text { University Faculty ( } \mathrm{n}=48)\end{array}$ & $38 \%$ & $62 \%$ & $42 \%$ & $58 \%$ & $94 \%$ & $6 \%$ & $35 \%$ & $65 \%$ \\
\hline $\begin{array}{l}\text { Rosati (1999) University of } \\
\text { Western Ontario (n=53) }\end{array}$ & $51 \%$ & $49 \%$ & $40 \%$ & $60 \%$ & $94 \%$ & $6 \%$ & $53 \%$ & $47 \%$ \\
\hline
\end{tabular}

Again, while the findings of the current study are not generalisable due to the sample sizes, the results for both the graduate e-learner and e-educator cohorts are similar to the small number of studies that have examined the learning styles of educators (academics/faculty). In their larger research cohorts, both Rosati (1996) and Zywno (2003) found academics to have preferences for intuitive and visual learning, aligning with the results of this study. Similar to the results of this study, Rosati (1999) found $51 \%$ of academics preferred active learning and Zywno (2003) found that $65 \%$ of academics preferred global learning (Table 3 ).

\section{Qualitative results}

While the overall quantitative findings of the research might be of no surprise for some readers in discerning the specific cohort divergence and homogeneity, the research also tested the anecdotal and intuitive understandings of learning style preferences (Ryan, 2010), as learning styles are a reflection of individual diversity. Learning styles research clearly relies on self-reporting data collection and this may not match the participant's beliefs. To overcome this limitation, Schunk (2004) has recommended the addition of multiple assessment instruments such as oral and written data to capture the 'individual variation'; the learner's voice. As such, this study added the usually absent opportunity for qualitative responses on learning styles by asking participants to provide feedback on their ILS results. While the majority of the research participants chose not to respond at all to this invitation, or provided simple email acknowledgments such as "Thanks for that" and "Great", a few participants from the 
educator and graduate e-learner cohorts offered some insightful responses concerning their self-perceptions and their results.

Participant E33 scored a moderate preference for reflective learning, a moderate preference for intuitive learning (preferring theoretical content), a mild preference for verbal learning, and a mild preference for global learning. E33 replied:

I found this very interesting and am not in the least surprised by the results. I do think that my learning style has changed as I have gotten older. I believe that I probably learn more easily at the ends of the scales and I think the processing [active/ reflective domain] and perceiving [sensing/intuitive domain] scores have been moderated over time. I think the receiving information [visual/verbal domain] score is right...

E33's opinion is therefore that her learning style preferences on some domains have changed over time. This observation is consistent with Felder and Brent's (2005) observation that learning styles can moderate over time and through experience.

The ILS results for respondent E31 revealed a mild preference for reflective learning, moderate preferences for sensing and verbal learning, and a strong preference for sequential learning. E31's response speculated that an educator's teaching style may be reflective of their own learning style:

From my perspective, the results are fairly accurate in terms of my learning style. I guess one also teaches using the same style as we learn, as that is the style we know works (at least for us) and are most comfortable with.

Participant E35 scored moderate preferences for active and global learning, and strong preferences for both intuitive and visual learning. E35 offered a comment concerning learning styles and the relevance that it has for instructional design in higher education:

Rather than being a concept to be dismissed, learning styles is a useful descriptive and indicative tool - just like litmus - rather than being prescriptive or predictive.

Participant E19 scored a mild preference for reflective learning, strong preferences for intuitive and visual learning, and a moderate preference for global learning. In the explanatory sheet on learning styles results, global learners are described as being "able to solve complex problems quickly or put things together in novel ways once they have grasped the big picture, but they may have difficulty explaining how they did it" (Felder \& Soloman, 1993). In a reply to receiving the ILS results, E19 stated:

I found the results quite fascinating, in that it helped me understand that sometimes I just see things/solutions and don't quite know how I did that...so it is quite confirming.

However E30, who scored a strong preference for visual learning offered a different type of comment to his ILS results. E30 stated: "I like images, but not at the expense of verbal information". This comment suggests the need for both dimensions on the learning style domains to be present within the instructional design and supports the stance for balanced ID.

A graduate e-learner (G5) scored mild preferences for active, sensing, and sequential learning, and a moderate preference for visual learning. G5 was quite clear as to her 
learning style preferences, sharing her frustration at ID that does not cater for diversity through 'one-size-fits-all' approaches. She stated comprehensively:

I prefer to [listen to] a lecture... take notes and do independent research and reading. I do not learn well by group activities [and] find most [group] exercises to be a waste of time and $[\mathrm{I}]$ am frustrated by having to accommodate the learning styles of others in time which I have had to fight to set aside for my own learning.

Such a comment touches on the impact of other student-related issues within the elearning environment. This student was a mature-aged distance learner with both work and family responsibilities in addition to her study load. For her, collaboration was perceived as getting in the way of personally achieving her study.

A similar conviction was shared by graduate e-learner G6 who scored a mild preference for verbal learning, moderate preferences for intuitive and global learning, and a strong preference for active learning. G6 added a comment aimed at those designing 'one-size-fits-all' e-learning environments that encourage collaboration on every task: "Don't waste my time"! Holding a similar view, participant G4 - who scored a moderate preference for reflective learning and strong preferences for intuitive, visual and global learning - stated:

My university is hung up on this collaborative approach, and on a synchronous and interactive pedagogical approach. I don't think this is necessary and it greatly irritates me.

Clearly, collaboration is not desired by all.

\section{Discussion}

The alignment of results between the graduate e-learners and e-educators across all four domains on the ILS in the current study warrants consideration. In an interview with Professor Richard Felder - the co-creator of the ILS - for the purposes of this research, I postulated that this seemed to be supportive evidence that learning styles can change over time as one goes through the progression from undergraduate to graduate to educator; however he proposed an alternative proposition:

[I think] it's more a self-selection process. It's most obvious in the sensing-intuiting balance. The undergraduates, most of whom are sensors and so real-world oriented, get out into the real world as quickly as they can, while the intuitors are the ones who tend to go on to graduate school, where they often leave the real world completely for years, and they're the ones who go on to earn PhDs and become educators. (Felder, 2007)

While both suggestions are worthy of further consideration, this may have implications for ID. Felder (1993) suggests that the teaching styles of educators are often not aligned with the learning styles of students who enter university and that the resultant ID can be either a reflection of their own learning style preferences or a consequence of academic tradition and reflecting the manner in which they were taught.

The undergraduate results in this study diverged with those of the graduate e-learners and e-educators on both sensing-intuitive and sequential-global domains, potentially supporting the previously noted correlation on these dimensions by Felder and Spurlin (2005) and Graf (2007). The results would suggest from a cohort perspective 
that ID should factor in different strategies for undergraduate e-learners (Clark \& Mayer, 2011) than for graduate e-learners and e-educators.

Table 4: Balancing ID for individual learning style preferences

\begin{tabular}{|c|}
\hline $\begin{array}{l}\text { Domain } 1 \text { - Processing information } \\
\text { Designing for active and reflective learning preferences }\end{array}$ \\
\hline $\begin{array}{l}\text { For active learning: include collaborative options such as group discussions, role plays } \\
\text { and problem-based learning scenarios. Appropriate media includes forums, wikis, } \\
\text { social networking sites or virtual worlds. } \\
\text { For reflective learning: include opportunities for quiet reflection, period review } \\
\text { questions, and personal summaries such as blog entries. Appropriate media includes } \\
\text { blogs, email, reports or essays. } \\
\text { Note: Scaffold each type of activity or assessment by building in incremental steps to } \\
\text { assist those who are not comfortable with each type of learning. }\end{array}$ \\
\hline $\begin{array}{c}\text { Domain } 2 \text { - Perceiving information } \\
\text { Designing for sensing and intuitive preferences } \\
\end{array}$ \\
\hline $\begin{array}{l}\text { For sensing learning: include opportunities to enable learners to connect information } \\
\text { to real-world scenarios such as experiments and fieldtrips. Appropriate media } \\
\text { includes simulations, PBL sites or virtual worlds. } \\
\text { For intuitive learning: include opportunities for abstract theoretical thought. } \\
\text { Appropriate media includes written documents such as essays, products or reports. } \\
\text { Note: Scaffold each type of activity or assessment by building in incremental steps to } \\
\text { assist those who are not comfortable with each type of learning. }\end{array}$ \\
\hline $\begin{array}{c}\text { Domain } 3 \text { - Receiving information } \\
\text { Designing for visual and verbal learning preferences } \\
\end{array}$ \\
\hline $\begin{array}{l}\text { For visual learning: include opportunities for the learners to use visual representations } \\
\text { such as mind maps, diagrams, videos and photographs. Appropriate media includes } \\
\text { social networking sites, videos, animation and modelling, interactive whiteboards. } \\
\text { For verbal learning: include opportunities for presenting learning in written or spoken } \\
\text { formats. Appropriate media includes wikis, blogs, forums, Skype and podcasts. } \\
\text { Note: Scaffold each type of activity or assessment by building in incremental steps to } \\
\text { assist those who are not comfortable with each type of learning. }\end{array}$ \\
\hline $\begin{array}{c}\text { Domain } 4 \text { - Understanding information } \\
\text { Designing for sequential and global learning preferences }\end{array}$ \\
\hline $\begin{array}{l}\text { For sequential learning: include opportunities for learners to begin with the basic } \\
\text { concepts and build up to the whole. Appropriate media includes print-based } \\
\text { materials such as text. In hypermedia environments include forward and back } \\
\text { options for linear learning progression (see Bajraktarevic et al., 2003). } \\
\text { For global learning: include opportunities to see the big picture in order for the } \\
\text { understanding of its constituent parts, such as mind maps and flow charts. } \\
\text { Appropriate media includes virtual worlds which can make holistic or 3D views } \\
\text { possible. In hypermedia environments, include a site overview, embedded URLs and } \\
\text { content tabs (see Bajraktarevic et al., 2003). } \\
\text { Note: Scaffold each type of activity or assessment by building in incremental steps to } \\
\text { assist those who are not comfortable with each type of learning. }\end{array}$ \\
\hline
\end{tabular}

Yet, in spite of cohort tendencies, learning style preferences also relate to individual diversity and designing for the majority in a cohort can still mean that others within that cohort are disadvantaged (Willems \& Reed, 2007). However, one challenge in providing balanced ID is developing a program in which educators utilise different 
teaching approaches with varied learning and assessment activities in order to cater for diversity. The danger is that this practice "can lead to what might be seen as a type of 'pedagogical sheep dip' where teaching strategies aim explicitly to touch upon all styles at some point in a formal programme" (Coffield et al., 2004, p. 3) and further, may not achieve the intended goal of helping learners build skills across each learning style domain to overcome this. Some suggestions for the construction of balanced elearning products using the learning styles domains on the ILS are listed in Table 4.

\section{Conclusion}

This paper has explored learning style variances between three cohorts in e-learning environments: novice undergraduate e-learners, graduate e-learners, and educators teaching in, or designing for, e-learning environments. The quantitative findings revealed an alignment between the learning styles of the graduate e-learner cohort and the e-educators across all four learning style domains on the ILS. Further, the results from both the e-educator and graduate e-learners diverged from the novice undergraduate e-learners on two domains: information perception (sensing-intuitive) $(p=0.015)$ and information understanding (sequential-global) $(p=0.007)$. The implications are that there are differences in learning styles between the those commencing their journey in higher education and with those who are further advanced in their formal studies or who design and/or teach in the learning environments. On the basis of cohort homogeneity, these results might be used to inform certain ID directions.

However, learning styles are one aspect of learner diversity, and are as such individual preferences. Therefore the need for balance in ID is suggested, using an instrument such as the ILS as a litmus test to ensure a well-rounded environment. Careful scaffolding of tasks within that environment is necessary in order to assist those develop skills in activities and tasks that are counter to their own learning style preferences. This also prevents the temptation to provide a bit of everything - a 'pedagogical sheep dip' (Coffield et al., 2004, p. 3) - in order to address diversity.

Additionally, participants were also invited to comment on their ILS results. While few in number, these comments provided insights into participant self-reflections that are generally absent from learning styles research, especially on the relationship between perceived personal learning style preferences and the ID of their learning environment. In turn, these implications warrant consideration in ID, but done so in a balanced and scaffolded manner to motivate a deep approach to learning. Finally, due to the small sample sizes in this research, a larger scale mixed-method study contrasting the three cohorts is recommended.

\section{Acknowledgments}

My appreciative thanks to Professor Richard Felder, Hoechst Celanese Professor Emeritus of Chemical Engineering at North Carolina State University, for his interview (1 October, 2007); to my former doctoral supervisors at Monash University (Dr Sue Yell and Associate Professor Peter Murphy); and to Professor Kinshuk, Professor Ron Oliver and to Professor Yoni Ryan for their additional suggestions. Gratitude is also due to the AJET reviewers and editors for their guidance in the refinement of this publication. 


\section{References}

Allinson, C. W. \& Hayes, J. (2000). Cross-national differences in cognitive style: Implications for management. International Journal of Human Resource Management, 11(1), 161-170. http: / / dx.doi.org/10.1080/095851900340042

Anohina, A. (2005). Analysis of the terminology used in the field of virtual learning. Educational Technology \& Society, 8(3), 91-102. http:/ / www.ifets.info/journals/8_3/9.pdf

Bajraktarevic, N., Hall, W. \& Fullick, P. (2003). Incorporating learning styles in hypermedia environments: Empirical evaluation.[viewed 4 Jul 2008, verified 26 Aug 2011] http: / / wwwis.win.tue.nl/ah2003/ proceedings/www-4 /

Belenky, M. F., Clinchy, B. M., Goldberger, R. N. \& Tarule, J. M. (1986). Women's ways of knowing: The development of self, voice, and mind. New York: Basic Books.

Bolea, B. (2006). Letter to the Editor: An overemphasis on learning styles. The Chronicle of Higher Education, 52(30), n.p.

Bousbia, N., Rebai, I., Labat, J.-M. \& Balla, A. (2010). Analysing the relationship between learning styles and navigation behaviour in web-based educational system. Knowledge Management \& E-Learning: An International Journal, 2(4), 400-421. http:/ / www.kmeljournal.org/ojs / index.php/online-publication/article/viewFile/22/ 64

Bowles, M. S. (2004). Relearning to e-learn: Strategies for electronic learning and knowledge. Melbourne: Melbourne University Press.

Brown, A.R. \& Votlz, B.D. (2005). Elements of effective e-learning design. The International Review of Research in Open and Distance Learning, 6(1).

http: / / www.irrodl.org/index.php/irrodl/article/view/217/300

Brown, T., Zoghi, M., Williams, B., Jaberzadeh, S., Roller, L., Palermo, C., McKenna, L., Wright, C., Baird, M., Schneider-Kolsky, M., Hewitt, L., Sim, J. \& Holt, T-A. (2009). Are learning style preferences of health science students predictive of their attitudes towards e-learning? Australasian Journal of Educational Technology, 25(4), 524-543. http: / / www.ascilite.org.au/ajet/ajet25/brown.html

Butler, K. A. (1986). Learning and teaching style in theory and practice. Melbourne: Hawker Brownlow Education.

Clark, D. R. (2007). Defining e-learning. [viewed 11 Feb 2008, verified 26 Aug 2011] http: / / www.nwlink.com/ donclark/hrd/ elearning/define.html

Clark, R. C. \& Mayer, R. M. (2011). E-learning and the science of instruction (3rd ed.). San Francisco, CA: Pfeiffer.

Coffield, F., Moseley, D., Hall, E. \& Ecclestone, K. (2004). Learning styles and pedagogy in post-16 learning: A systematic and critical review. [viewed 25 July 2011] http: / / www.hull.ac.uk/php/edskas/learning\%20styles.pdf

Conner, M. L. \& Conner, K. W. (2006). e-Learning. Ageless Learner. [viewed 11 Feb 2008, verified 26 Aug 2011] http: / / agelesslearner.com/intros/elearning.html

Cohen, L. \& Manion, L. (1994). Research methods in education (4th ed.). London: Routledge. 
Cross, J. (1998). Internet Time Machine. TechLearn 98, Orlando, Florida. [viewed 2 March 2008] http: / / metatime.blogspot.com/2004/11/techlearn.html; http: / / www.internettime.com/itimegroup/techlearn/sld001.htm

Dede, C. (2005). Planning for neomillennial learning styles. EDUCAUSE Quarterly, 1, 7-12. [viewed 4 July 2008, verified 26 Aug 2011] http: / / net.educause.edu/ir/library/pdf/EQM0511.pdf

Downes, S. (2005). E-learning 2.0. E-Learn Magazine. October 2005 [viewed 14 April 2011] http: / / elearnmag.acm.org / featured.cfm?aid=1104968

Driscoll, M. (2002). Web-based training: Creating e-learning experiences. San Francisco, CA: JosseyBass / Pfeiffer.

Felder, R. M. (1993). Reaching the second tier: Learning and teaching styles in college science education. College Science Teaching, 23(5) 286-290. [verified 26 Aug 2011] http: / / www4.ncsu.edu/unity/lockers/ users/f/felder/public/Papers/Secondtier.html

Felder, R. M. (1996). Matters of style. ASEE Prism, 6(4), 18-23.

Felder, R. M. (2006). Index of Learning Styles (ILS). [viewed 26 January 2006, verified 26 Aug 2011] http: / / www4.ncsu.edu/unity/lockers/ users/f / felder/public/ILSpage.html

Felder, R. M. (2007). Interview. North Carolina State University, Carey, NC: 1 October 2007.

Felder, R. M. \& Brent, R. (2005). Understanding student differences. Journal of Engineering Education, 94(1), 57-72. http: / / www4.ncsu.edu/ unity/lockers/users/f/felder/public/ Papers/Understanding_Differences.pdf

Felder, R. M. \& Silverman, L. K. (1988). Learning and teaching styles in engineering education. Engineering Education, 78(7), 674-681. [verified 26 Aug 2011] http: / / www4.ncsu.edu/unity / lockers / users / f / felder/public/Papers/LS-1988.pdf

Felder, R. M. \& Soloman, B. A. (1991, 1994). Index of Learning Styles. [verified 26 Aug 2011] http: / / www4.ncsu.edu/unity/lockers/ users/f/felder/public/ILSdir/ILS.pdf

Felder, R. M. \& Soloman, B. (1993). Learning styles and strategies. [viewed 18 January 2006] http: / / www4.ncsu.edu/unity/lockers/users/f/felder/public/ILSdir/styles.htm

Felder, R. M. \& Spurlin, J. E. (2005). A validation study of the Index of Learning Styles. Applications, reliability, and validity of the Index of Learning Styles. International Journal of Engineering Education, 21(1), 103-112. [verified 26 Aug 2011] http:/ / www4.ncsu.edu/unity / lockers / users / f / felder/public/ILSdir/ILS_Validation(IJEE).pdf

Ford, R. (1997). Educational anthropology: Early history and educationist contributors. In G. Spindler (Ed.), Education and cultural process: Anthropological approaches (3rd ed.). Prospect Heights, IL: Waveland Press.

Fournier, H., Dragne, C. \& Romila, D. (2006). State of the Field Report of Adult Learning Research: Elearning. Ottawa, Canada: National Research Council Canada, Institute for Information Technology. http:/ / www.cclcca.ca/pdfs / AdLKC/ stateofthefieldreports / FINALSUMMARYE-learning.pdf

Gibbs, D. \& Gosper, M. (2006). The upside-down-world of e-learning. Journal of Learning Design, 1(2), 46-54. http: / / www.jld.qut.edu.au/ publications/vol1no2/documents / upside $\% 20$ down\%20world.pdf 
Gillard, J. (2009). Speech to the Universities Australia Conference, 4 March 2009, Canberra. [viewed 22 April 2009, verified 27 Aug 2011] http:/ / www.deewr.gov.au/Ministers/ Gillard/Media/Speeches/Pages / Article_090304_155721.aspx

Graf, S. (2007). Adaptivity in learning management systems focussing on learning styles. Unpublished doctoral dissertation, Vienna University of Technology, Austria. http:// www.big.tuwien.ac.at/teaching/theses/77

Graf, S. \& Kinshuk (2007). Providing adaptive courses in learning management systems with respect to learning styles. In T. Bastiaens \& S. Carliner (Eds.), Proceedings of World Conference on E-Learning in Corporate, Government, Healthcare, and Higher Education 2007 (pp. 2576-2583). Chesapeake, VA: AACE.

http:/ / wit.at/people/graf/publications/graf_kinshuk_eLearn2007.pdf

Grasha, A. F. (1984). Learning styles: The journey from Greenwich Observatory (1976) to the college classroom (1984). Improving College and University Teaching, 32(1), 46-53.

Greenman, N.P. (2005). Anthropology applied to education. In S. Kedia \& J. Van Willigen (Eds.) Applied anthropology: Domains of application (pp. 263-306). Westport, CT: Greenwood Publishing Group.

Hou, M. H., Sobieraj, S., Pronovost, S., Roberts, S. \& Banbury, S. (2010). Suitable learning styles for intelligent tutoring technologies. Defense Research and Development Canada. http:// pubs.drdc.gc.ca/inbasket/mhou.100916_1316.Toronto_TR_2010_073_Revised.pdf [viewed 18 May 2011, verified 27 Aug 2011]

Karrer, T. (2007). Understanding e-learning 2.0. [viewed 18 July 2011] http:/ / www.astd.org/LC/2007/0707_karrer.htm

Kleinfeld, J. \& Nelson, P. (1991). Adapting instruction to Native Americans' learning styles: An iconoclastic view. Journal of Cross-Cultural Psychology, 22, 273-282.

Kolb, D. A. (1984). Experiential Learning: Experience as the source of learning and development. Englewood Cliffs, NJ: Prentice-Hall.

Kratzig, G. P. \& Arbuthnott, K.D. (2006). Perceptual learning style and learning proficiency: A test of the hypothesis. Journal of Educational Psychology, 98(1), 238-246.

Laurillard, D. (2002). Rethinking university teaching: A conversational framework for the effective use of learning technologies. (2nd ed.). London and New York: Routledge/Falmer.

Leiba, M. \& Nachmias, R. (2006). Web usage patterns and learning styles in an academic course in engineering. Proceedings of the International Conference on Information Communication Technologies in Education (ICICTE 2006), Rhodes, Greece. [viewed 15 July 2008] http: / / telaviv.academia.edu / MosheLeiba/ Papers / 278587/WEB_USAGE_PATTERNS_AN D_LEARNING_STYLES_IN_AN_ACADEMIC_COURSE_IN_ENGINEERING

Lopes, W. M. G. (2002). ILS - Invetário de estilos de aprendizagem de Felder-Soloman: Investigação de sua validade em estudentes universitários del Belo Horinzonte. Masters thesis: Universidade Federal de Santa Caterina, Brazil.

Mariani, L. (2004). Learning styles across cultures. Perspectives: A journal of TESOL Italy, 34(2). [viewed 4 July 2008, verified 27 Aug 2011] http: / / www.learningpaths.org/papers/ paperculturalstyles.htm 
McLoughlin, C. (1999). The implications of the research literature on learning styles for the design of instructional material. Australian Journal of Educational Technology, 15(3), 222-241. http:/ / www.ascilite.org.au/ajet/ajet15/mcloughlin.html

Morri, A. (1997). A bright future for distance learning: One Touch/Hughes alliance promotes interactive 'e-learning' service. Connected Planet Online, 17 November. [viewed 11 Feb 2008 verified 27 Aug 2011] http:/ / telephonyonline.com/mag/telecom_bright_future_distance/

Morrison, M., Sweeney, A. \& Heffernan, T. W. (2003). Learning styles of on-campus and offcampus marketing students: The challenge for marketing educators. Journal of Marketing Education, 25(3), 208-217. http: / / dx.doi.org/10.1177/0273475303257520

NIV Study Bible (1985). The Holy Bible, New International Version. Grand Rapids, MI: Zondervan Corporation.

Oblinger, D. G. \& Hawkins, B.L. (2005). The myth about e-learning: “We don't need to worry about e-learning any more". EDUCAUSE Review, July/August, 14-15. http: / / net.educause.edu/ir/library/pdf/erm05411.pdf

Palloff, R. M. \& Pratt, K. (2003). The virtual student: A profile and guide to working with online learners. San Francisco, CA: Jossey-Bass.

Paredes, P. \& Rodríguez, P. (2004). A mixed approach to modelling learning styles in adaptive educational hypermedia. Advanced Technology for Learning, 1(4), 210-215. http: / / www.actapress.com / Abstract.aspx?paperId=16231

Pashler, H., McDaniel, M., Rohrer, D. \& Bjork, R. (2008). Learning styles: Concepts and evidence. Psychological Science in the Public Interest, 9(3), 105-119. http: / / dx.doi.org/10.1111/j.15396053.2009.01038.x

Philbin, M., Meier, E., Huffman, S. \& Boverie, P. (1995). A survey of gender and learning styles. Sex Roles, 32(7-8), 485-494. http:/ / dx.doi.org/10.1007 /BF01544184

Roffe, I. (2002). E-learning: Engagement, enhancement and execution. Quality Assurance in Education, 10(1), 40-50. http: / / dx.doi.org/10.1108/09684880210416102

Rojas, V. H. (2009). Learning styles don't exist? [blog posting; viewed 18 July 2011] http: / / victorhugor.blogspot.com/2009/05/learning-styles-dont-exist-willingham.html

Rosati, P. A. (1999). Specific differences and similarities in the learning preferences of engineering students. Proceedings Frontiers in Education Conference 1999 IEEE (Session 12c1), San Juan, Puerto Rico. http:/ / dx.doi.org/10.1109/ FIE.1999.841625

Ryan, Y. (2010). Personal correspondence.

Schunk, D. H. (2004). Learning theories: An educational perspective. (4th ed.). Upper Saddle River, NJ: Pearson Education.

Sims, S. J. \& Sims, R. R. (2006). Learning styles, decontextualized testing, and the need for styleswitching in minority students. In R. R. Sims \& S. J. Sims (Eds.), Learning styles and learning: A key to meeting accountability demands in education. (pp. 191-209). New York: Nova Science Publishers.

Siemens, G. (2004). Categories of eLearning. Elearnspace. [viewed 16 Feb 2008] http: / / www.elearnspace.org/ Articles/elearningcategories.htm 
Suskie, L. (2002). Theories and instruments for identifying student learning styles. [viewed 25 Oct 2004, not found 27 Aug 2011] http:/ / wwwnew.towson.edu/iact/teaching/Suskie LearningStylesTheoriesandInstruments.doc

Tucker, R. (2007). Southern drift: The learning styles of first- and third-year students of the built environment. Architectural Science Review, 50(3), 246-255. http: / / dx.doi.org/10.3763/asre.2007.5030

Vandiver, D. M. \& Walsh, J. A. (2010). Assessing autonomous learning in research methods courses: Implementing the student-driven research project. Active Learning in Higher Education, 11(1), 31-42. http: / / dx.doi.org/10.1177/ 1469787409355877

Wagner, E. (2011). Essay: In search of the secret handshakes of ID. The Journal of Applied Instructional Design, 1(1), 33-37. http:/ / www.jaidpub.org/wpcontent/uploads/2011/03/EssayWagnerApr2011.pdf

Wheeler, S. (2007). Learning with 'e's: Defining technology supported e-learning within a knowledge economy. Paper presented at the ICICTE Conference, Heraklion, Greece, 12-14 July. http:/ / www2.plymouth.ac.uk/ distancelearning/steve.html [viewed 25 Feb 2009] http: / / www2.plymouth.ac.uk/ distancelearning/ICICTE2007.doc

Willems, J. (2005). Flexible learning: Implications of 'when-ever', ‘where-ever' and 'what-ever'. Distance Education, 26(3), 429-435. http: / / dx.doi.org/10.1080/01587910500291579

Willems, J. (2010). Does style matter? Considering the impact of learning styles in e-learning. Doctoral thesis. Monash University.

http: / / arrow.monash.edu.au/vital/access / manager/ Repository / monash:34655

Willems, J. \& Reed, L. (2007). Beyond delivery: A case study in e-learning for podiatry students. T. Bastiaens \& S. Carliner (Eds.), World Conference on E-learning in Corporate, Government, Healthcare and Higher Education. Proceedings E-Learn Quebec City 2007 (pp. 6664-6671). Chesapeake, VA: AACE. http:/ / eprints.qut.edu.au/13972/1/13972.pdf

Willingham, D. (2008). Learning styles don't exist. [YouTube; viewed 18 July 2011] http: / / www.youtube.com/watch?v=sIv9rz2NTUk

Zywno, M. S. (2003). A contribution to the validation of score meaning for Felder-Soloman's Index of Learning Styles. Proceedings of Annual ASEE Conference 2003 (Session 2351). [viewed 5 Apr 2008, verified 27 Aug 2011] http:/ / soa.asee.org/ paper/conference/ paperview.cfm?id=19037

Author: Dr Julie Willems, Honorary Adjunct

School of Education, Faculty of the Professions

University of New England, NSW 2351, Australia

Email: Julie.Willems@une.edu.au Web: http:/ / www.dehub.edu.au/

Please cite as: Willems, J. (2011). Using learning styles data to inform e-learning design: A study comparing undergraduates, postgraduates and e-educators. Australasian Journal of Educational Technology, 27(6), 863-880.

http: / / www.ascilite.org.au/ajet/ ajet27 / willems.html 